\title{
The Necessity of the Dialogue Between Judaism and Christianity
}

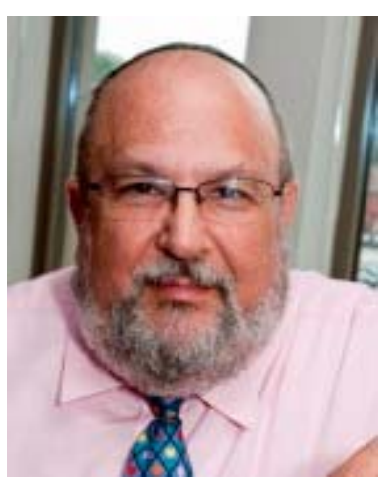

Daniel J. Lasker is the Norbert Blechner Professor of Jewish Values in the GoldsteinGoren Department of Jewish Thought at Israel's Ben-Gurion University of the Negev, in Beer Sheva, Israel. His areas of interest are medieval Jewish philosophy (including the thought of Rabbi Judah Halevi, Maimonides, and Rabbi Hasdai Crescas), the JewishChristian debate, Karaism, and selected issues in Jewish theology and law. His first book, Jewish Philosophical Polemics Against Christianity (1977; second edition, 2007), details the use of philosophy in the medieval Jewish critique of Christianity, and subsequent works have included editions and translations of a number of polemical treatises. From Judah Hadassi to Elijah Bashyatchi: Studies in Late Medieval Karaite Philosophy (2008), describes developments in Byzantine Karaite philosophy from the twelfth to fifteenth centuries, and his latest book, The Sage Simhah Isaac Lutski. An Eighteenth-Century Karaite Rabbi. Selected Writings (2015), presents annotated editions of Lutski's treatises. He has over 200 other publications as well. In addition to Ben-Gurion University, Prof. Lasker has taught at University of Toronto, Yale University, Princeton University, Ohio State University, University of Texas, University of Washington, and other institutions.

Tudor Petcu: The relation between Judaism and Christianity represents a subject that obligates us to think more about history which hasn't facilitated too well the possibility of a strong dialogue. If I say that Christians have a historical responsibility to reexamine their cultural and ethical behavior regarding the Jews, I think I say everything, but I'm not quite sure about one fact. I don't know how much Christians have managed to eliminate their prejudices and to understand that you can't be a real Christian if you are at the same time anti-Semitic. So, what do you think about that? In your opinion, how does, the present dialogue between Judaism and Christianity look like?

Daniel J. Lasker: For most of its history, Christian thinkers taught that the delegitimization of Judaism was necessary for the justification of Christianity. This delegitimization did not necessarily include active persecution of Jews, but it often led to discriminatory legislation; false accusations of ritual murder, host desecration, and well-poisoning; massacres of Jewish populations; forced conversions; expropriation of property and expulsions. Although many Christian theologians upheld Augustine's view that Jews were to be allowed to remain in Christian countries (albeit in a subordinate status), Christian rulers and their populations often found Jews convenient scapegoats and objects of persecution. An almost natural consequence of this delegitimization of Judaism was modern secular anti-Semitism which culminated in the Holocaust.

Even though the Nazis were not traditional Christians, much of their ideology drew upon Christian anti-Jewish sources, including Luther's virulent anti-Judaism. In the light of the Holocaust, many Christians felt true remorse that their teachings of supersession and triumphalism led to such horrible consequences. Therefore, since World War II, many Christians, most notably the Catholic Church whose general silence during the Holocaust is still a very sore point among Jews, sought a way of reinterpreting Christianity such that there is still a place for Jews and Judaism in the divine economy after what they believed was the Incarnation and subsequent fulfillment of the law by the crucifixion. 
As a result of these changes in Christian teaching, expressed most prominently in Vatican II's Nostre Aetate, Christians have looked for ways to reinterpret traditional Christian teachings to eliminate anti-Semitism. The "Jews" of the Gospels, especially John, are understood to be some Judeans and not all Jews. The onus for the execution of Jesus has generally passed over to the Romans and away from Jews, despite the presumed quotation: His blood be upon us and our children. In short, many Christians today are doing their best to reinterpret Christianity so as to preserve their belief in Jesus' salvation without necessarily denigrating Judaism and present-day Jews. To the extent that Christians have succeeded in reworking their view of Jews and Judaism, they have made dialogue between Jews and Christians possible and have demonstrated that believing in Christianity did not force the believer to be anti-Semitic. Not all Christians share the goal of legitimizing Judaism, even in those churches, such as the Catholic Church, where reinterpretation of the place of Judaism in the divine plan is official policy.

Jews and Christians also have succeeded in maintaining cordial relations concerning issues of joint interest even in the absence of theological changes. In the US, Orthodox Jews and Catholics are interested in state support of parochial schools; these groups and some Evangelicals cooperate in the fight against abortion and the acceptance of same sex relations and marriage. Many Jews are willing to cooperate with Evangelicals in support of the State of Israel. Liberal Jews and Christians often share political and social goals. This has occurred in the absence of any new theological understandings.

Tudor Petcu: What holds Jews and Christians together is certainly the Old Testament, and especially, the Patriarch Abraham. But, I think Christians have forgotten the importance of the Old Testament, believing that the New Testament is the only way by which they can gain redemption. From this point of view I would be very pleased if you could explain the importance of the Old Testament so that our Christian readers can better understand their Jewish heritage.

Daniel J. Lasker: Jews do not consider the Hebrew Bible to be an "Old Testament." If there is a sequel to the Hebrew Bible, it is the "Oral Torah," codified in the Talmud and subsequent law codes which are the basis of Jewish observance to this day. Christians, however, cannot ignore Hebrew Scriptures since the Manichean attempt of rejecting the Jewish revelation in favor of exclusive reliance upon the Greek scriptures has always been rejected by orthodox Christianity. From the Jewish point of view, however, the reading of the Hebrew Bible as an Old Testament which is fulfilled only in the New Testament is part of the delegitimization of Judaism I mentioned above. It would be most useful for Christians to read the Hebrew Bible on its own terms and appreciate how important it is for understanding both Judaism and Christianity. The concept of Messiah, although that term is not used in the Hebrew Bible in the context of future salvation, cannot be understood without its origins in the Hebrew Bible. When Christians do read the Hebrew Bible, it is imperative for Jewish-Christian understanding that Christians not try to appropriate the concept of "Israel" for themselves but rather understand how central the biblical narrative is for Jewish self-understanding.

Tudor Petcu: In the last, let's say, 40 years, some Christian representatives and thinkers have made a lot of efforts to heal the memory of the evil. And when I'm saying that, I make reference, of course, to the Holocaust, for which there is Christian culpability. When I'm talking about these efforts, I cannot forget about one of the most important Christian documents, which was approved during the Vatican II Council, called Nostra Aetate. How do you see this document? Can we say that it was an important step for a new era of the dialogue between Judaism and Christianity?

Daniel J. Lasker: Obviously, Nostra Aetate has had a central role to play in Jewish-Christian rapprochement since Vatican II. It should not be forgotten that this was a major step by the Catholic Church in an attempt to heal the wounds of the past. But it also should not be forgotten that for 
many Jews, this statement did not go nearly far enough to wipe out 2000 years of persecution and discrimination. The final text eliminated some of the unequivocal pro-Jewish language of the earlier drafts and also seemed to go out of its way to placate other groups which are not sympathetic to Jews and Judaism. Furthermore, many Jews believed that the charge of deicide was not accurate to begin with - why should the Catholic Church be congratulated for amending a position which was illegitimate at its inception? Some Jews still expect explicit apologies from Christians, especially from Catholics and the Pope, for Jewish suffering caused by Christians over the centuries and for what is perceived as Pope Pius XII's collaboration with the Nazis (and they demand the opening of Vatican archives). This is not easy for Catholics who see their predecessors as role-models (and often saints) despite some of their negative attitudes towards Jews. However one sees Nostra Aetate, it was obviously a milestone and many Jews hope that the Catholic Church will build upon this and eventually understand the pain and damage inflicted on the Jewish people in the name of Christianity.

Tudor Petcu: One of the most important Christian leaders, whose main purpose was the reconciliation with Judaism, was Pope John Paul II. During my researches on the relations between Jews and Christians, I've studied a lot his personality under this aspect. And now I remember very well two steps that he took for a new dialogue with Judaism: his meeting with Rabbi Elio Toaff, which, I think, meant a lot, and his document on the Shoah. Have these efforts made by Pope John Paul II been helpful for a better understanding between Jews and Christians?

Daniel J. Lasker: Pope John Paul II was perceived by many Jews as someone who truly wished to right the wrongs of the past; who was willing to recognize the State of Israel; as someone who was anti-Nazi and anti-Communist (the two great anti-Semitic movements); and as a Pole who empathized with the suffering of Jews especially on Polish soil. But I think that whoever would have been Pope, the historical processes set in motion by Pope John XXIII would have continued. Even Pope Benedict, a German who had been a member of Hitler Youth, was very conscious of the need to continue the dialogue with Jews that had been started by his predecessors. It should be remembered, however, that John Paul II's first and foremost consideration was the interests of the Catholic Church and not the sensitivities of the Jewish People.

Tudor Petcu: I am tempted to talk about a complementarity between Judaism and Christianity, because they have in common more than we can think. So, do you agree that this complementarity is an essential condition for a right understanding of the European identity?

Daniel J. Lasker: The concept of a Judeo-Christian tradition is very controversial. Obviously Judaism and Christianity have more in common with each other than either one has, e.g., with eastern religions. Although one can understand Judaism on its own terms without reference to Christianity while Christianity can be understood only in terms of Judaism, the Jewish encounter with Christianity has had a major effect on the development of Judaism in the past millennium. Thus a full understanding of Judaism requires a study of the Christian societies in which Jews lived.

In terms of European identity, it has been shaped not only by Christian doctrine but also by Christian delegitimization of Judaism. After all, it was in Europe that the Holocaust took place and it is Europe which judges the State of Israel by different standards than it judges other countries and peoples. Although European governments have tried to overcome anti-Semitism after World War II, it is still a powerful force in Europe, both among right wing nationalist parties and among the growing Muslim immigrant communities. Obviously, then, it is important for nominally Christian Europeans to understand Judaism and Jewish history in order for them to understand themselves better and to overcome the terrible events of the past. 